\title{
SIKAP PETANI TERHADAP PROFESI PETANI: UPAYA UNTUK MEMAHAMI PETANI MELALUI PENDEKATAN PSIKOLOGI SOSIAL (KASUS PETANI DI KECAMATAN PAUH, KOTA PADANG)
}

\author{
Farmers' Attitude toward Farmers Profession: Effort to Understanding \\ farmers through social Psychology (Farmer Case in Subdistrict of Pauh \\ City of Padang)
}

\author{
Nuraini Budi Astuti \\ Fakultas Pertanian Universitas Andalas Padang \\ Astuti_1901@yahoo.co.id
}

\begin{abstract}
The farmer behaviour is influenced by many factors and one of them is what the farmer's attitude toward his profession. In order to understand the farmer's behaviour, we have to understand the farmer's attitude in advance. The purposes of this study are: 1) to analyze the farmer's attitude toward his profession, 2) to describe the schematic attitute. The data for this study were analized quantitatively using likest scale and qualitatively using theories of social psicology. The finding shows that the farmers tend to have a positive attitude. Meanwhile the schematic attitude shows that the farmers attitude toward their professions was positive and negative. therefore, extension acctivities should emphasize on changing the aspect of negative attitude.
\end{abstract}

Key word: farmers, behaviour, attitude

\section{PENDAHULUAN}

Sebagai pelaku utama dalam pembangunan pertanian, petani menjadi faktor penentu dalam menyukseskan program-program dalam pertanian pertanian. Menurut Mardikanto (2007) dalam setiap proses pembangunan pertanian, kehadiran petani senantiasa memainkan peran ganda, baik sebagai:juru tani, pengelola usaha tani maupun sebagai manusia yang merupakan anggota dari keluarga dan sistem - sosial masyarakatnya.

Perilaku petani dalam berusahatani, dapat dipahami dengan menggunakan berbagai perspektif. Tulisan ini akan menggunakan perspektif kognitif dalam memahami perilaku petani. Perspektif kognitif memberikan penekanan atau perhatian pada aspek mental (sikap, motivasi dan persepsi) dalam memahami perilaku sosial. Penelitian ini akan fokus pada aspek sikap 
sebagai faktor yang mempengaruhi perilaku. Sikap sendiri diartikan sebagai kesiapan untuk selalu menanggapi dengan cara tertentu dan menekankan implikasi perilaku (Sears, Freedman dan Peplau, 1999).

Sikap memiliki tiga bagian atau domain yaitu kesadaran, pengetahuan atau keyakinan (cognitif), perasaan (afektif) dan kecenderungan bertingkahlaku (konasi) (Allport, 1954; Hilgart , 1980; McGuire, 1969; Ajzen, 1988 dalam Sarwono, 2002). Ketiganya memiliki hubungan erat dimana pengetahuan atau keyakinan akan suatu objek akan menimbulkan kan perasaan tertentu yang akan mendorong seseorang menamilkan perilaku tertentu. Lebih jauh Sarwono (2002) menjelasakan bahwa jika kita dapat mengetahui kognisi dann perasaan seseorang terhadap suatu objek sikap tertentu, maka kita akan tahu pula kecenderungan perilakunya.

Oleh kerena itu kajian-kajian perilaku petani perlu dilengkapi dengan sebuah kajian baru yang dapat memberikan penjelasan bagaimana sikap petani terhadap pekerjaannya (profesi petani). Hasil kajian ini dapat digunakan untuk memprediksi perilaku atau keputusan yang akan dibuat oleh petani berkaitan dengan usahataninya.

Berdasarkan penjelasan tersebut, maka pertanyaan penelitian yang kemudian muncul dari kondisi tersebut adalah bagaimana sikap petani terhadap profesi petani itu sendiri? Dengan demikian, tujuan penelitian ini adalag untuk menilai dan menganalisis sikap petani terhadap profesi petani dan mendeskripsikan skematik sikap.

\section{METODE PENELITIAN}

Penelitian ini dilakukan pada Bulan Juli hingga September tahun 2015 di Kecamatan Pauh, Kota Padang dengan menggunakan metode survei. Data dikumpulkan dengan cara observasi dan wawancara terstruktur dengan 100 orang responden yang dipilih secara acsidental sampling.

Variabel penelitian diturunkan dari pandangan ahli mengenai sikap yang berorientasi pada skema triadik. Sikap petani merupakan konstelasi tiga komponen yaitu: (a) Kognitif, (b) Afektif, dan (c) Konatif.

Untuk menilai sikap petani terhadap profesinya, diberikan 20 butir pernyataan yang terdiri dari delapan pernyataan terkait aspek penilaian dan dua belas pernyataan terkait aspek keyakinan. Pernyataan dibuat dalam bentuk kalimat positif dan negatif. Data selanjutnya akan dianalisis dengan menggunakan Skala Likert, dengan kategori jawaban dan penilai sebagai berikut:

60 | Nuraini Budi Astuti, Sikap Petani Terhadap Profesi Petani: Upaya untuk ... 
Tabel 1. Kategori jawaban berdasarkan Skala Likert

\begin{tabular}{lcc}
\hline \multirow{2}{*}{ Kategori Jawaban } & \multicolumn{2}{c}{ Skor } \\
\cline { 2 - 3 } & Pernyataan Positif & Peryataan Negatif \\
\hline Sangat setuju & 5 & 1 \\
Setuju & 4 & 2 \\
Ragu-ragu & 3 & 3 \\
tidak setuju & 2 & 4 \\
sangat tidak setuju & 1 & 5 \\
\hline
\end{tabular}

Hasil skoring kemudian dijumlahkan dan dirata-ratakan. Selanjutnya ratarat tersebut akan dinilai berdasarkan kategori berikut:

Tabel 2. Kategori penilaian sikap petani

\begin{tabular}{cc}
\hline Rentang Skor & Penilaian terhadap profesi petani \\
\hline $3,8-5,0$ & positif \\
$2,4-3,7$ & netral \\
$1-2,3$ & negatif \\
\hline
\end{tabular}

Penilai tersebut sesuai dengan dengan pendapat Luis Thurstone (1928), Rensis Likert (1932) dan Charles Osgood yang menyatakan sikap sebagai reaksi perasaan, derajad efek positif atau efek negatif terhadap suatu objek psikologis, (Edwars, dalam Sobur, 2013)

\section{HASIL DAN PEMBAHASAN}

Kecamatan Pauh merupakan salah satu kecamatan di Kota Padang yang memiliki luas 146,29 $\mathrm{km}^{2}$ lebih kurang 21,05\% dari total luas Kota Padang (101,03 $\mathrm{km}^{2}$ diantaranya adalah kawasan hutan lindung) dengan posisi $0^{0} 58^{\prime} 00^{\prime \prime}$ - 01' $08^{\prime \prime} 35^{\prime \prime}$ LS dan $100^{\circ} 21^{\prime \prime} 11^{\prime \prime}$ BT (BPS Kota Padang, 2012). Jumlah penduduk Kecamatan Pauh tahun 2013 adalah 64.864 jiwa. Komoditi pertanian yang utama adalah padi, jagung dan sayuran.

\section{Sikap Petani Terhadap Profesi Petani}

Berdasarkan analisis dengan Skala Likert didapatkan nilai rata-rata sikap sebesar 3,44 yang berarti masuk ke dalam kategori netral untuk skala 1 - 5 . Seperti dijelaskan sebelumnya, terdapat dua aspek pokok dalam hubungan antara sikap dengan perilaku, yaitu aspek penilaian dengan skor sebesar 3,43 dan aspek keyakinan sebesar 3, 63. Kedua aspek tersebut juga masuk kategori netral. 
Sikap netral yang ditunjukan oleh petani dapat dipahami sebagai sikap yang tidak terlalu tergantung kepada kegiatan pertanian. Hal tersebut dapat dipahami karena dari 100 orang petani yang diwawancarai ternyata hanya 30 orang $(30 \%)$ yang semata-mata bekerja sebagai petani. Artinya $70 \%$ responden lainnya memiliki pekerjaan lain di luar pertanian sehingga tidak hanya mengandalkan usaha tani saja. Hal ini merupakan karakteristik dari petani yang tinggal diperkotaan, dimana peluang untuk bekerja di luar berusaha tani cukup terbuka.

Sikap merupakan hasil dari proses mental yang termasuk ke dalam kategori perilaku tak tampak atau covert behavior. Sikap dipengaruhi oleh aspek penilaian dan aspek keyakinan terhadap objek sikap. Kasus di Kecamatan Pauh yang memberikan hasil bahwa sikap petani terhadap profesinya adalah netral. Ini memberikan informasi kepada kita bawa seseorang yang bersikap netral, akan menampakan perilaku yang sangat dipengaruhi oleh lingkungan eksternal (lingkungan sosial), artinya petani akan sangat mempertimbangkan pengaruh lingkungan sosialnya sebelum melakukan sesuatu terkait dengan usahataninya. Misalnya jika ada kegiatan penyuluhan petani dengan sikap netral akan cenderung tidak antusias kecuali jika dia mendapatkan pengaruh yang kuat dari orang-orang disekitarnya.

Penjelasan tersebut di dukung oleh teori medan (field theory) oleh Kurt Lewin (1935) dalam Shaw dan Costanzo (1985) yang menyatakan bahwa perilaku individu sangat dipengaruhi oleh situasi dimana individu itu berada. Lingkungan dapat berarti lingkungan fisik, lokasi atau tempat tinggal maupun lingkungan sosial.

\section{Skematik Sikap}

GW. Allport (1935) dalam Sear dan Freedman (1999) mengatakan bahwa, sikap adalah keadaan mental dan syaraf dari kesiapan, yang diatur melalui pengalaman yang memberikan pengaruh dinamik atau terarah terhadap respon indvidu terhadap semua objek dan situasi yang terkait degannya. Berdasarkan definisi tersebut dapat dipahami bahwa sikap terbentuk dari sekelompok kognisi dan perasaan yang berkaitan dengan objek sikap baik yang bernilai positif maupun negatif. Sekelompok kognisi dan perasaan tersebut tersebut akan membentuk skematik sikap. Penelitian mengenai sikap terhadap profesi petani, menghasilkan skematik sikap sebagai berikut: 


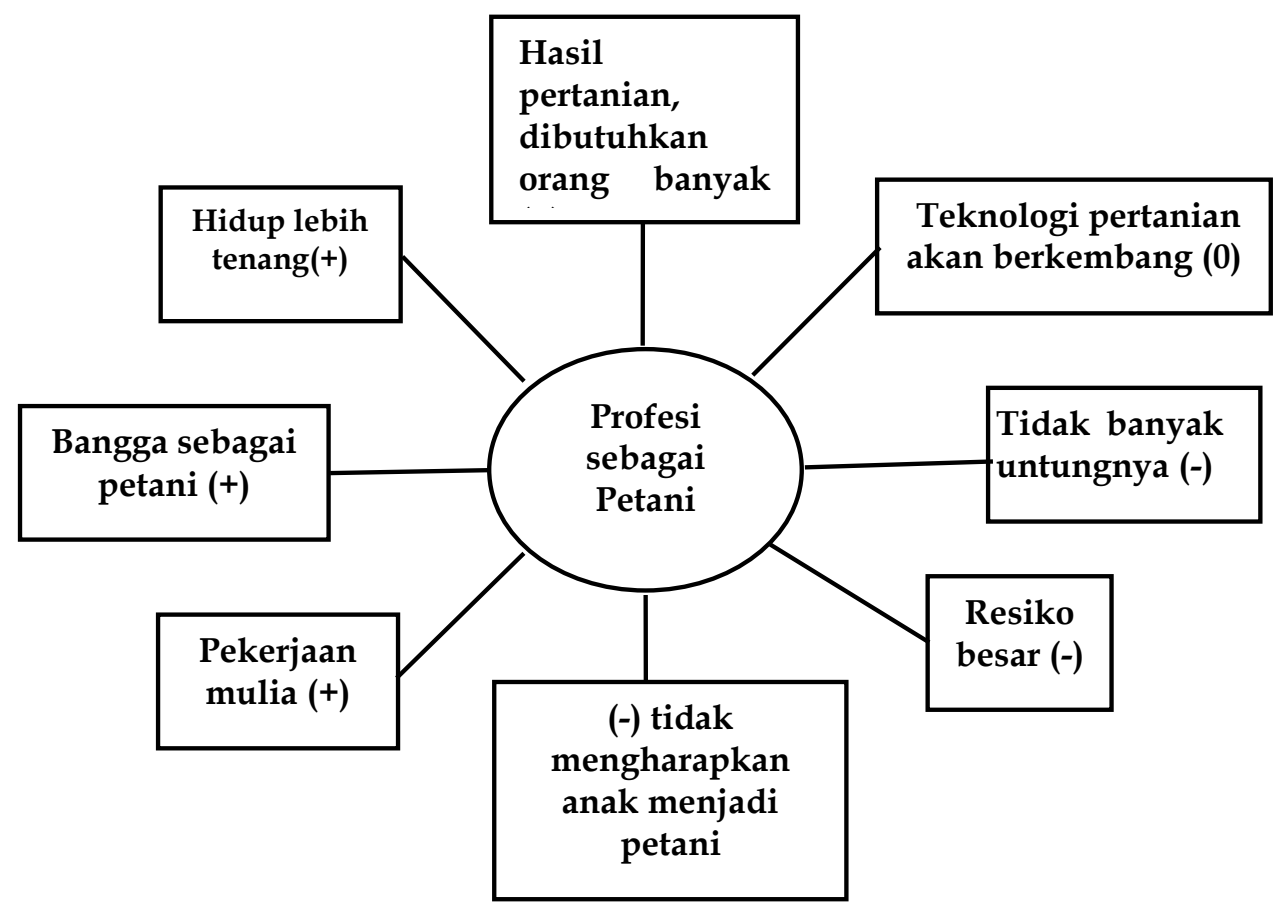

Gambar 1.

\section{Gambar Skematik Sikap Terhadap Profesi Petani}

Dari gambar di atas dapat dilihat bahwa sikap terhadap profesi petani selain mengandung penilaian netral (dilambangkan dengan angka 0), juga mengandung penilaian positif (dilambangkan dengan simbol + ) dan negatif (dilambangkan dengan simbol -). Dari 20 pernyataan yang diajukan kepada petani, 4 pernyataan memiliki rata-rata skor yang bernilai positif, 3 negatif dan sisanya sebanyak 13 pernyataan bernilai netral. Kombinasi dari semua penilaian tersebut pada akhirnya akan mempengaruhi perilaku petani dalam berusahatani.

Pendapat Myers (1996) dalam Sarwono (2002) mengatakan bahwa sikap memiliki tiga domain yang disingkat $\mathrm{ABC}$ (Affective, Behavior and Cognitive). Pendapat lain mengatakan bahwa domain sikap terdiri dari kognitif, afektif dan konatif. Ini seperti yang dinyatakan oleh Allport (1954), Hilgard (1980), McGuire (1969), Ajzen (1988) dalam Sarwono (2002). Konatif dimaknai sebagai kecenderungan untuk berperilaku.

Karena ketiga domain itu saling terikat erat maka timbul teori bahwa jika kita dapat mengetahui kognisi dan perasaan seseorang terhadap suatu objek 
sikap tertentu, maka kita akan tahu pula kecenderungan perilakunya. Namun gambaran skematik pada Gambar 1, memberikan penjelasan bahwa, meskipun terdapat penilaian negaif terhadap profesi petani, tidak menghalangi orang untuk tetap bekerja sebagai petani.

Adanya penilaian positif dan negatif dari petani terhadap profesinya menunjukan sikap mabivalensi dalam diri petani. Menurut Baron dan Byrne (2004), ambivalensi sikap, merujuk pada kenyataan, bahwa evaluasi kita terhadap objek tidak selalu secara seragam positif atau negatif, sebaliknya, seringkali tercampur, terdiridari dua reaksi, baik positif, maupun negatif. Dari data yang telah ditampilkan terlihat bahwa, meskipun memiliki dua penilaian atas profesi petani (positif dan negatif) namun penilaian yang cenderung positif ternyata kebanyakan berada pada aspek afektif. Sementara penilaian negatif terhadap profesi petani berada pada ranah kognitif.

Menurut Sarwono (2002) komponen kognitif lebih mudah diubah. Sedangkan penilaian positif yang berada pada komponen emosional atau komponen evaluatif yang merupakan domain dari afektif. Komponen afektif lebih dapat bertahan dan lebih pokok daripada komponen kognitif. Berikut penjelasan aspek yang bernilai positif dan negatif

\section{Petani Sebagai Pekerjaan Yang Mulia}

Pernyataan ini mempunyai rata-rata skor 4,26 (kategori positif), 100\% petani memberika respon satuju hingga sangat setuju terhadap pernyataan ini. Ini adalah pernyataan yang tergolong kepada ranah afektif. Nilai positif untuk ranah afektif, seperti yang pernah diungkapkan akan sulit untuk berubah.

\section{Bangga Sebagai Petani}

Ini juga pernyataan dalam ranah afektif yang bernilai 4,42 (positif). Kebanggaan sebagai petani tampaknya juga sejalan dengan sikap positif atas perasaan yang menganggap bertani sebagai pekerjaan yang mulia. Kebanggaan sebagai petani membuat mereka tetap melakoni perkerjaan ini meskipun ada pekerjaan lain.

\section{Bertani Memberikan Kehidupan Yang Lebih Tenang}

Pernyataan ini mempunyai rata-rata skor 4,02 yang berarti bernilai positif. Pernyataan ini berada pada ranah afektif. Ketenangan bekerja sebagai petani pada dasarnya timbul dari keyakinan bahwa produk pertanian diperlukan sebagai penopang kehidupan. Sehingga petani tidak khawatir produksinya tidak laku. 


\section{Hasil Pertanian Pasti Diperlukan Banyak Orang Sehingga Mudah Menjualnya}

Ini pernyataan dalam ranah kognitif dengan rata-rata skor 3,97 (bernilai positif). Hal ini sesuai dengan penjelasan sebelumnya yang juga merupakan sikap yang optimis. Tentu tidak bisa dibantah bahwa hasil pertanian diperlukan oleh banyak orang yang berarti banyak permintaan, sehingga hasil pertanian tidak memiliki kesuliitan dalam hal pemasaran.

\section{Pekerjaan petani tidak banyak untungnya}

Pernyataan ini masuk kategori ranah kognitif dengan nilai sikap sebesar 2,2 (negatif). Kerena dinyatakan dalam kalimat negatif, semakin kecil nilainya berarti menunjukan persetujuan petani atas pernyataan tersebut artinya petani setuju bahwa bertani tidak banyak untungnya. Namun sesuai dengan teori yang mengatakan bahwa ranah kognitif memiliki kemungkinan untuk berubah ini sekaligus menjelaskan bahwa walaupun kurang menguntungkan namun mereka tetap mempertahankan pekerjaan tersebut. Keuntungan dari bertani dapat saja berubah menjadi lebih tinggi apabila terjadi kemungkinan harga produk pertanian menjadi lebih yang tinggi, biaya produksi yang rendah atau permintaan terhadap produk bertambah.

\section{Tidak Mengharapkan Anak Untuk Menjadi Petani}

Pernyataan ini masuk ke ranah kognitif dengan nilai 2,01 (negatif). Kerena dinyatakan dalam kalimat negatif, semakin kecil nilainya berarti menunjukan persetujuan petani atas pernyataan tersebut. Artinya petani setuju dengan pernyataan ini. Hal ini dapat dipahami sebagai karena setia orang tua pasti menginginkan hidup yang lebih baik bagi anak-anaknya. Kerena petani beranggapan bahwa bertani tidak banyak untungnya dan pekerjaan di luar pertanian cenderung lebih menjanjikan. Oleh karena itu dapat diterima bahwa petani tidak mengharapkan anaknya menjadi petani juga. Karena setiap orang tua tentu mengharapkan anaknya lebih baik.

\section{SIMPULAN DAN SARAN}

\section{Simpulan}

1. Meskipun sikap petani terhadap profesi petani ternyata masuk kategori positif namun terdapat ambivalensi sikap dimana ada dua reaksi yaitu positif dan negatif terhadap objek sikap.

2. Faktor-faktor sosial yang mempengaruhi sikap terhadap profesi petani secara signifikan adalah tingkat pendidikan dan status pekerjaan. Artinya semakin tinggi tingkat pendidikan seseorang semakin positif sikapnya terhadap profesi petani. Dan semakin bergantung seseorang kepada 
pekerjaan sebagai petani semakin positif pula sikapnya terhadap profesi tersebut.

\section{SARAN}

1. Karena petani memliki sikap yang netral terhadap pekerjaannya, maka kegiatan penyuluhan sebaiknya dilakukan dengan intensif dan diperkuat dengan pendekatan terhadap reference group untuk lebih meyakinkan petani.

2. Materi penyuluhan megenai perbaikan metoda berusahatani atauun inovasi teknologi, sebaiknya juga diperkaya dengan analisis usaha tani untuk memberikan penjelasan akan potensi keuntungan yang mungkin didapatkan oleh petani jika menerapkan hal tersebut.

\section{DAFTAR PUSTAKA}

Badan Pusat Statistik. 2002. Kota Padang dalam Angka. http//www.padangkota.bps.go.id

Baron, Robert dan Byrne, Donn. 2003. Psikologi Sosial Jilid 1. Penerbit Erlangga. Jakarta.

Mardikato, Totok. 2007. Pengantar Ilmu Pertanian. Pusat Pengembangan Agrobisnis dan Perhutan Sosial. SurakartaMueller,J.H Schuessler. 1977. Statistical Reasoning in Sociology. Boston: Houghton Mifflin Company.

Sarwono, Sarlito Wirawan.2002. Psikologi Sosial: Individu dan Teori-teori Psikologi Sosial. Penerbit Balai Pustaka. Jakarta

Sears David O, Freedman Jonathan L dan Peplau L Anne. 1999. Psikologi Sosial. Penerbit Erlangga. Jakarta

Shaw Marvin E.and Philip R. Costanzo Theories of Social Psychology -, Second Edition, 1985, McGraw-Hill, Inc.

Sobur, Alex. 2003. Psikologi Umum, dalam lintasan sejarah, Penerbit Pustaka setia. Bandung 